$126 \cdot 4$

\title{
Salomé!! Sarah Bernhardt, Oscar Wilde, and the Drama of Celebrity
}

\author{
SHARON MARCUS
}

SHARON MARCUS is Orlando Harriman Professor of English and Comparative Literature at Columbia University. The author of Apartment Stories: City and Home in Nineteenth-Century Paris and London ( $\mathrm{U}$ of California P, 1999) and of the prizewinning Between Women: Friendship, Desire, and Marriage in Victorian England (Princeton UP, 2007), she is working on a book about theatrical celebrity in the nineteenth century and recently wrote "The Theater of Comparative Literature" for A Companion to Comparative Literature (ed. Ali Behdad and Dominic Thomas; Wiley, 2011).
${ }^{16}$ ARAH VA JOUER SALOMÉ!!" FOR READERS TODAY, OSCAR WILDE'S Salome is best known as a literary object, the 1894 English edition whose stylized Aubrey Beardsley drawings and archaic prose accentuated the decadent qualities of the work Wilde originally wrote in French. For the play's author and public, however, Salome was also a dramatic event, identified with the celebrity actress Sarah Bernhardt, whose agreement to play the title role in 1892 sent Wilde into raptures-“Sarah is going to play Salome!!"-when he relayed the news to a fellow author ("To Pierre Louÿs"; June 1892; Holland and Hart-Davis 529). The drama continued when Salome was denied a license for performance in London, putting Wilde where he had so often placed himself-in the public spotlight. Because scholars often study nineteenth-century dramatic texts and performance culture in isolation from each other, I begin with Wilde's exclamation (and will return to it) as an emblem of my argument that during this period celebrity informed drama and theatricality structured celebrity. (Whether the argument holds for other times and genres is outside the scope of this essay.) Read on to discover the connections between a star author, a celebrity actress, and the scandalous work of art that brought them together; read on for an account of how Salome, a play in which almost every character is both fan and idol, represents the theatricality of celebrity in its themes and form.

Nineteenth-century celebrity was theatrical not simply in the anecdotal sense that many celebrities were actors; it was also theatrical in structure, by which I mean organized around nonreciprocal exhibition and attention, around the asymmetrical interdependence that obtains between actors and audiences. Many have argued that all celebrities are actors because they impersonate a fabricated role

(C) 2011 BY THE MODERN LANGUAGE ASSOCIATION OF AMERICA 
and purvey a duplicitous illusion. By contrast, I define celebrity as theatrical because it combines proximity and distance and links celebrities to their devotees in structurally uneven ways. The star is one, the fans are many, just as audience members outnumber players. Stars are known to and tracked by more people than they could ever personally know or follow (Mills 72), just as in dramatic performance actors who move and speak onstage rarely, if ever, acknowledge spectators who watch and listen. For all their asymmetry, however, celebrity and theatricality are also organized around interdependence, since plays and stars exist only because of audiences and fans.

Wilde's play similarly revolves around obsessive attention and desire, portrays objects of fascination as surrounded by barriers even when on display, and depicts attempts to breach the distance between spectacle and spectator as dangerous failures. As a preview, consider Iokanaan (Wilde's name for John the Baptist), who fascinates Salome with his dramatic rants but forbids her to breach the distance between them: "Back, daughter of Sodom! Do not touch me. One must not profane the temple of the Lord God" ("Arrière, fille de Sodome! Ne me touchez pas. Il ne faut pas profaner le temple du Seigneur Dieu"; 23; 33). ${ }^{1}$ Salome, angered by Iokanaan's repulsion, demands his head on a silver platter, then reproaches it for not having returned her gaze: "why did you not look at me, Iokanaan? ... I saw you, Iokanaan, and I loved you" ("pourquoi ne m'as-tu pas regardée, Iokanaan? . . . Moi, je t'ai vu, Iokanaan, et je t'ai aimé"; 65; 82). The futility of posing such questions to a lifelesss body part exemplifies the lack of correspondence that obtains between characters throughout the play.

Though theatrical in structure, celebrity was also a social, political, and material phenomenon. Socially, celebrities ranged between exemplarity and impudence and absorbed religious energies and roles even as they transformed them. Politically, celebrity culture melded absolutism and democracy. Aesthetically, celebrity relied both on the star's bodily presence and on representations that substituted for it. Theatricality's asymmetrical interdependence inflected each of these aspects of celebrity. Impudent celebrities were impervious to their difference from the norm but needed to display their indifference to the conforming crowd. Often deemed royal and divine, stars, like modern gods and kings, depended for their power on the populace that worshipped them. Nineteenth-century idols had a physical presence, but their incarnations were rendered glamorous by press coverage and visual imagery, and their live appearances registered untouchable distance from the audience as much as thrilling proximity to it.

This essay offers a theory of celebrity, a historical account of Sarah Bernhardt and Oscar Wilde as celebrities, and an interpretation of Salome as staging celebrity through its formal emphasis on asymmetrical gazes, desire, and speech and through its thematic preoccupations with impudence, religion, populism, and bodily presence. ${ }^{2}$ Holding the mirror of Salome up to reflect the nature of celebrity, the argument unfolds by re-creating associations and contexts, since the claim that drama informed celebrity and celebrity shaped drama is a historical and structural one best illustrated cumulatively. After making this point in general terms, I dramatize it by juxtaposing scenes from Salome with episodes from Bernhardt's and Wilde's careers, finding resonances of the actress's stardom and the author's notoriety in the play itself. The essay thus reenacts the oscillations that Salome's original readers and viewers would have experienced as they wove between absorption in its fictional events and awareness of the storied celebrities who brought it to life.

In theorizing celebrity, I build on the work of previous scholars, especially Richard Dyer and Joseph Roach. However, where Dyer focuses on stars constrained by film studios, I focus on a stage diva known for control- 
ling her career. Where Roach explores "It," a transhistorical, innate quality, I focus on a specifically theatrical and deliberately crafted celebrity. ${ }^{3}$ I share with Roach and Dyer, however, a less censorious view of celebrity than the one prevalent in academic discourse. Intellectuals love to hate celebrity culture, viewing it as frivolous at best, pernicious at worst (Morin; Braudy; Gitlin; Schickel; Rojek). Most dismiss fans as gullible and fickle, celebrities as artificial, venal, and shallow, and denounce the star system for conflating publicity and privacy, triviality and seriousness, and ephemerality and immortality. Many oversimplify celebrity by splitting it, labeling it either fully participatory or thoroughly manufactured, radically democratic or incipiently fascist, blasphemously secular or the newest expression of religious impulses, a rallying point for individualism or the imposition of mindless conformity. One could temporize that celebrity is sometimes some of these things, sometimes others, but celebrity is always all these things: its omnivorousness is how and why it works (Dyer 36; Roach 8).

The oxymoronic structure of celebrity may explain its attractions for Oscar Wilde, an author famously drawn to paradox. $\mathrm{Sa}$ lome, Wilde's greatest meditation on celebrity, is a one-act drama, composed in French in 1891, denied a license for performance in the summer of 1892, and published in French in February 1893 and in English in 1894. Although Salome's biblical setting may seem too archaic to generate celebrities, the play became an episode in the history of celebrity when Wilde announced that Sarah Bernhardt, the world's most famous actress, would play the title character. Bernhardt was a perfect choice, despite being almost fifty. She had just impressed spectators as a nineteenyear-old Joan of Arc, and while Wilde was composing his play in Paris, Bernhardt was incarnating a sexy Cleopatra (fig. 1), one of her many roles as the type of orientalized, queer femme fatale evoked by Salome ("Idol-
Woman"; Gilman; Raafat; Powell, Oscar Wilde 45). Casting Bernhardt was a canny move, given Wilde's plan to premiere his play in London not in English but in French. For over a decade, Bernhardt had drawn audiences worldwide while performing exclusively in French, and she had an especially close relationship with the London public, which had made her an international star in 1879.

With good reason, therefore, Wilde trumpeted Bernhardt's willingness to take on his lead role when in June 1892 he wrote to Pierre Louÿs, "Sarah va jouer Salomé!!" Wilde's double exclamation points and internal rhymes reveal an artless glee rare in his correspondence, a delight in being on a firstname basis with a star. The sentence's brevity, also unusual, alerts us to the fit between actress and role by accentuating the acoustic similarity between "Sarah" and "Salomé," both Jewish names. The chiastic symmetry of the phrase, which begins with a name and a verb ("Sarah va") and ends with a verb and a title ("jouer Salomé"), makes Sarah and Salomé into reflections of each other, just as the play's title mirrors its protagonist's name. Wilde's sentence enacts what it announces, turning Sarah into Salomé and Salomé into an emanation of the star actress.

Celebrity linked Salome's author and star well before Bernhardt agreed to play the title role in Wilde's play. As early as 1880 , newspapers were calling Bernhardt "the most famous woman in France" (Picon 133), and the press began calling Wilde a celebrity as early as 1882 (Oscar Wilde's Visit; "Days"). Journalists identified them both as publicity hounds. A British reviewer in 1910 noted that Bernhardt was not only "a great actress" but also "unequalled" as "a purveyor of good 'copy" (London); a British journalist in 1893 lambasted Wilde for "mistaking a forgotten butterfly notoriety for permanent fame" (Truth).

By the time Bernhardt agreed to play Salome, she and Wilde each had been subjects of "Bijou Portraits" in the periodical Society and 
had their hands studied by Cheiro, celebrity palmist to kings and queens (Busson 59; McKenna 229). ${ }^{4}$ Both had made lucrative tours of the United States, she performing in plays, he giving lectures; both had typed themselves by designing their own clothes and adopting flowers as signature accessories; and both had been frequently caricatured by the illustrated

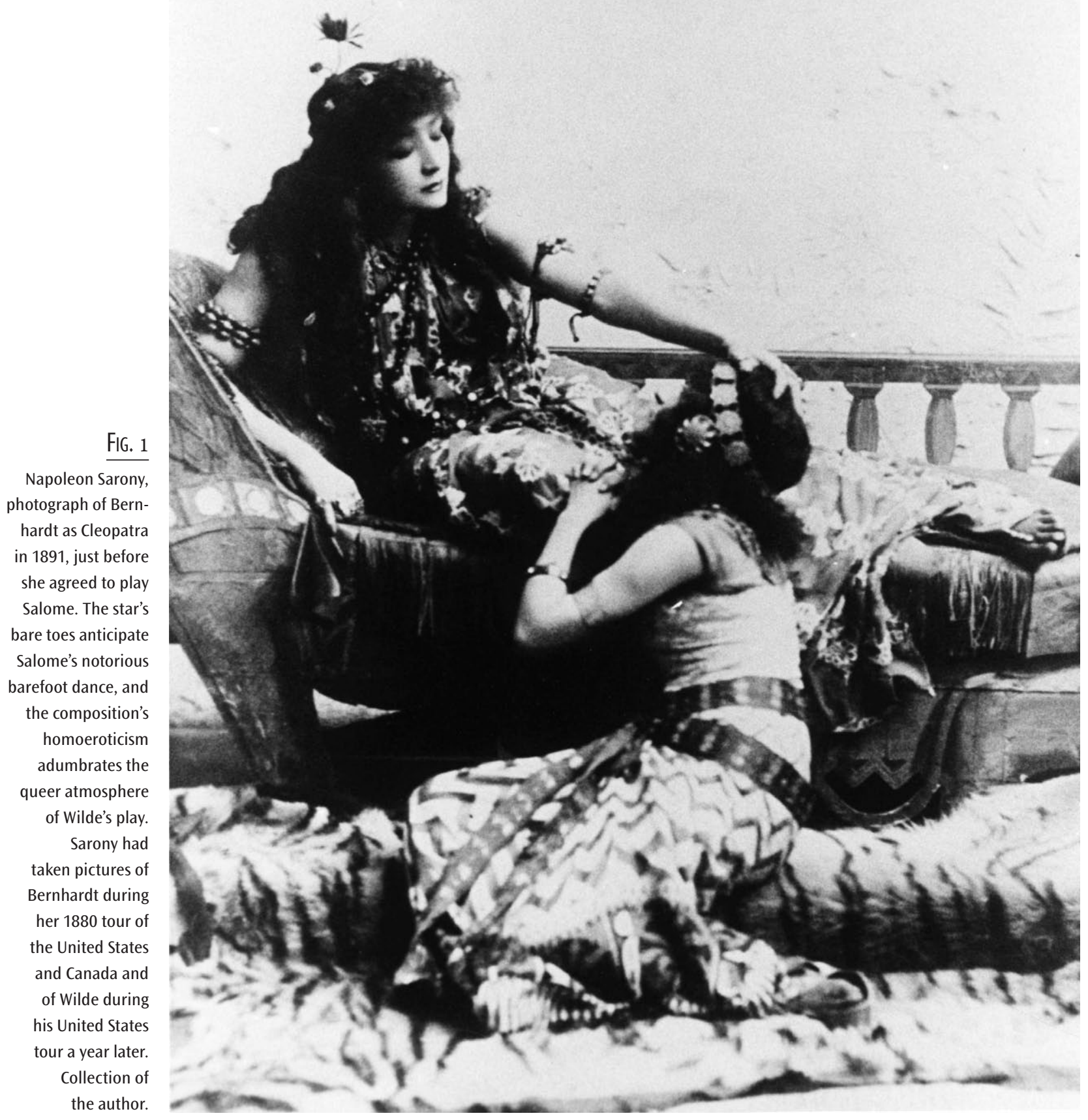


press of several nations. Actress and author alike deftly used photography, advertising, the mass press, and international travel to gain public recognition (Guibert; Ockman; Gagnier; Novak; Bristow, Introd.). Their celebrity was thus part of the event that was Salome well before the lord chamberlain's examiner of plays refused the play a license for production in July 1892 and inadvertently demonstrated that there is no bad publicity. British journalists took sides for and against the play, Wilde defended his artistic stature by protesting this affront to it, and Salome remained a magnet for scandal well into the twentieth century (Walkowitz; Lewsadder; Simon).

\section{Celebrity and Theatricality}

To understand Salome, we must first define celebrity and its relation to theatricality. Theatricality is a mode of representation organized around the presence of live actors and audiences, whose relation to each other is asymmetrical. Unlike textual representations, which represent actions as printed signs that are usually read silently, individually, and in private, theatrical imitations of action take the form of action itself, and actors present the characters they embody directly to publicly gathered spectators (Garner 13; Hart 33). The stage body is not a natural body; it depends on written texts and other recorded media (Auslander) and needs lighting, acoustics, costume, makeup, blocking, and training to become vivid and audible. Theatrical presence is thus not metaphysical (transcendent, complete, self-identical) but physical, situated, directional, and intersubjective, since actors are always oriented to spectators and to one another (States 14). To act is "to be there... in front of." Dramatic action is presented, addressed, and demands a response; its "frontal" energy comes from the actor's confrontation of the audience, which generates theatrical "presence" and "manifestation" (Guénoun 15).
Theatrical presence also depends on the asymmetry between actor and audience: "the difference between the one who performs and the one who listens is the play"; the play consists in the fact "that one person plays and not the other, who watches" (9; see also States; Garner). Onstage, argues the philosopher and theater practitioner Denis Guénoun, two orientations interact: the lateral, in which one faces one's partners in play and presents the audience one's profile, thus creating an image, and the frontal, "rock star" orientation, which persists even in the most naturalistic theater (13). For Guénoun, presence on the modern stage results from the combination of address and reticence, proximity and distance, that arises with the convention of the fourth wall (17). When actors no longer directly address the audience, as Shakespearean clowns did and as rock stars still often do, the result is theatrical presence-the intensified sense of play created when an actor performs in front of an audience that listens and watches but neither overtly acknowledges the other. Because actors ignore spectators in order to concentrate spectatorial attention, the fourth wall is not a refusal to acknowledge the audience but a deeper solicitation of it; it does not reject theatricality but intensifies it.

Celebrity, like theater, combines referents and signs, presence and representation, intimacy and distance; it is verbal and scriptive, improvisatory and text-based, autocratic and dependent on the audience it seeks to please. Stars are recognizable in person because of the widespread circulation of iconic, indexical representations that register simultaneously their physical absence and their existence in the flesh. Celebrity is premised on the belief that a single, unique individual brings to life a given star persona-hence the fan's hope of glimpsing a star in person (Dames). To be sure, even as celebrity confects a fantasy about peerless, inimitable presence, it turns individuality into a tissue of citations, since not only are stars widely copied, they 
often present themselves as copies: Lady Gaga echoes Madonna echoing Marilyn echoing Jean Harlow; Wilde echoed Byron echoing Brummel. Yet despite, or because of, this dependence on imitation and reproduction, a star made recognizable by representation will cause the greatest stir by appearing in person.

Presence was an even more salient feature of celebrity before cinema. For most of the nineteenth century, celebrity representations existed primarily to induce people to go see stars perform live. The articles and photographs we now use to reconstruct thespian careers were almost all occasioned by actors' visits to cities and towns, and viewing live performers was a common experience in an era when people of all classes went to the theater several times a week. Sound and film recordings of stage actors were rare for most of the nineteenth century, and commercial photographs, though compelling, did not substitute for hearing and seeing stars in person. Indeed, the images of stage actors that circulated throughout the nineteenth century did not efface theatrical aura but supplemented it; the haunting absent presence that defines photography and the exaggerated use of color, line, and scale in posters only intensified the aura of singular reality around performers appearing in person. As Walter Benjamin put it, "[T]he artistic performance of a stage actor is definitely presented to the public by the actor in person. ... [A] ] ura is tied to [the actor's] presence; there can be no replica of it" (228-29). Even today, mechanically reproducible media stoke the desire to experience celebrity presence, as we see every time a movie star draws crowds to the theater (as Al Pacino did when he played Herod in a staged reading of Salome).

In the case of Sarah Bernhardt, an actress known for her distinctive voice and dramatic sinuosity, photographs and posters brought the star just close enough to remind viewers what was missing: the presence they could experience at the theater. Bernhardt cannily extended her stardom by posing for photographs, commissioning posters, and selling her name and image to advertisers ("Entr'acte"). Photographs, however, were the property of photographers (North), who kept profits from sales, paying one-time fees to celebrity sitters, for whom such images were not ends in themselves. Nineteenth-century actors did not present themselves onstage to sell representations; they used representations to sell theater tickets. Bernhardt became a star by circulating not only her image but also her person on an almost superhuman scale, traveling multiple times across the world to perform in venues that included elite theaters, music halls, and vaudeville tents. On an American tour, she commissioned a specially outfitted train dubbed the Sarah Bernhardt, underscoring that her global stardom meant being at once an image, a name, a machine, and a body in perpetual motion, traveling at record-breaking speeds to town after town in order to be seen live and in person (fig. 2).

Accounts of Bernhardt's performances attest to her powerful stage presence. Wilde himself wrote, after seeing her perform in 1879, "Sarah Bernhardt's Phèdre was the most splendid creation I ever witnessed. The scene only lasted 10 minutes yet she worked the audience to a strained pitch of excitement such as I never saw" (“To Oscar Browning"; 3 June 1879; Holland and Hart-Davis 80). Contemporaries wrote of her expressive physicality: "everything in her person speaks: the eyes, the gestures, and the entire body as much as her lips" (Fourcaud 12). Bernhardt gave many the impression that she could reach across the footlights to touch, even attack, the audience. The nineteenth-century drama critic Arsène Houssaye declaimed, "Her voice is by turns a caress and a dagger's blow.... [S] he is stronger than the spectators when she wants to strike them right in the chest with some natural and characteristic words." Onstage, Bernhardt's flexible body conveyed a contained mobility, a coiled vitality even when at rest (Ockman 29; 


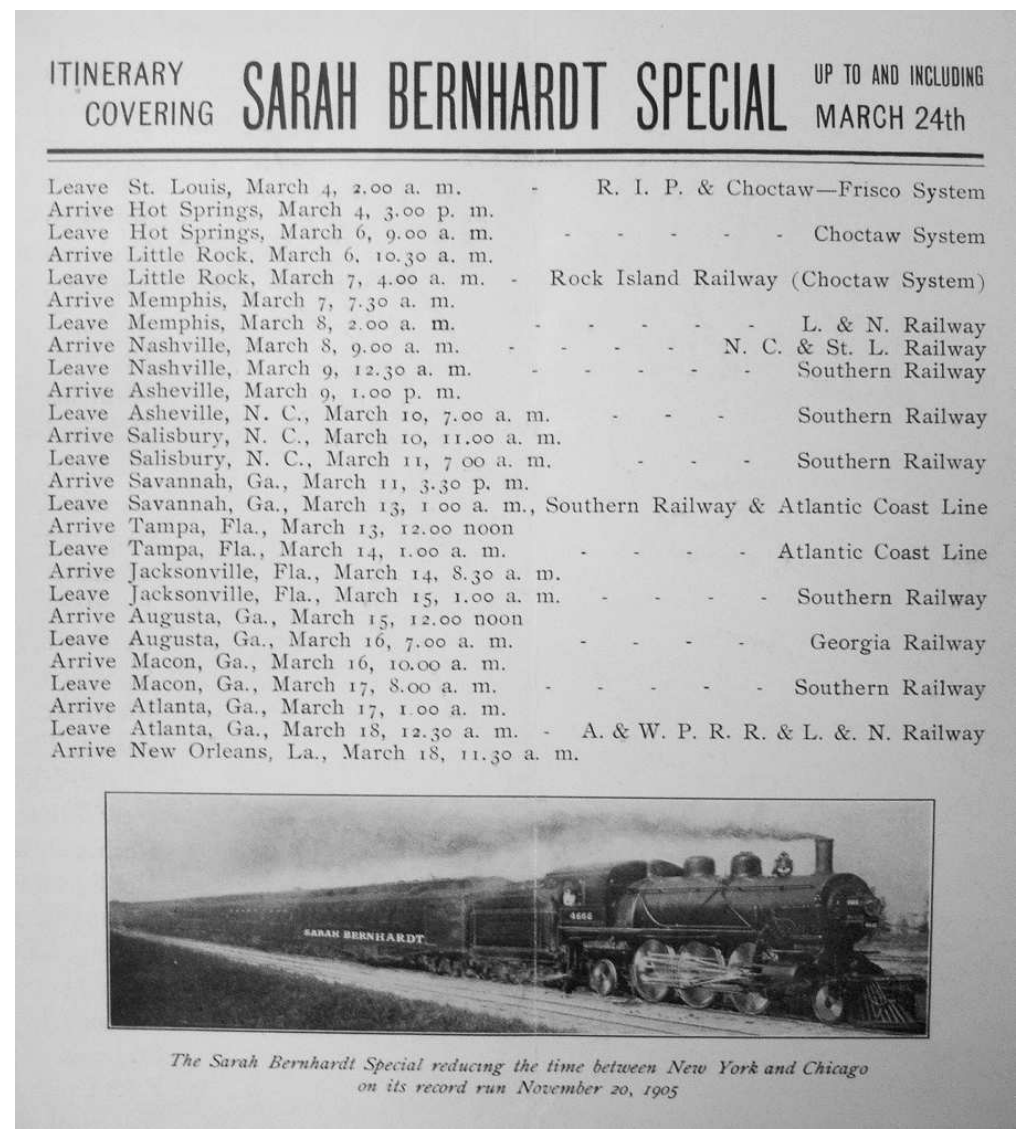

FIG. 2

Itinerary of the Sarah Bernhardt, 1905. The train transporting Bernhardt across the United States becomes a marquee in motion. This metonym for the actress, a container identified with and advertising the star it contains, endows the words "Sarah Bernhardt" with the modernity of speed, the evanescence of smoke, and the propulsive momentum of an object moving at a record-breaking pace toward the beholder. Courtesy of the Biblothèque Nationale de France, Arts du Spectacle.

Picon 75-76). Her ability to twist and spiral her scandalously uncorseted form became a metaphor for features of her celebrity persona that the press both celebrated and mocked: the capacity to bend around obstacles, to reconfigure norms at will, and to create herself, to become her own signature by making her body itself into a sinuous $S$, the letter she claimed as her first initial when she changed her name from Rosine to Sarah (figs. 3 and 4).

\section{Salome's Theory of Celebrity}

Salome, like theatrical celebrity, is about the interplay between presence and mediation, display and distance, acting and watching, talking and listening, getting paid and paying. Just as celebrity combines presence and representation, so Salome combines a theater of action and a theater of narration, or what Martin Puchner has termed a theater of mimesis and a theater of diegesis. The play's investment in a theater of narration is obvious. Although Salome has been successfully staged many times (Kaplan), it is also a symbolist work written as much to be read as to be performed. Its reliance on elaborate figurative language often seems to make the characters stand for the process of representation itself. When not converting one another into elaborate similes, characters narrate the action in verbal bursts that function almost like intertitles. In the play's opening scene, for example, before Salome has made her entrance, the Young Syrian tells us what she is doing offstage: "the princess is getting up! She is leaving the table! She looks very troubled" ("la princesse se lève! Elle quitte la table! Elle a l'air très ennuyée"; 9; 18). So much of Salome involves characters talking about what they 
FIG. 3

H. Scott and

G. Clairin, drawing of Bernhardt accompanying an article in La vie moderne 2 Oct. 1880: 639. Bernhardt is depicted as a winged angel in flight, lifted above clouds and birds.

The $S$ shape traced by the undulating arc that begins with the hand on the right and ends with the rising twist of the ruffled skirt on the left echoes the reversed and horizontal $S$ shapes curving around the capital letter L. Courtesy of the New York Public Library.

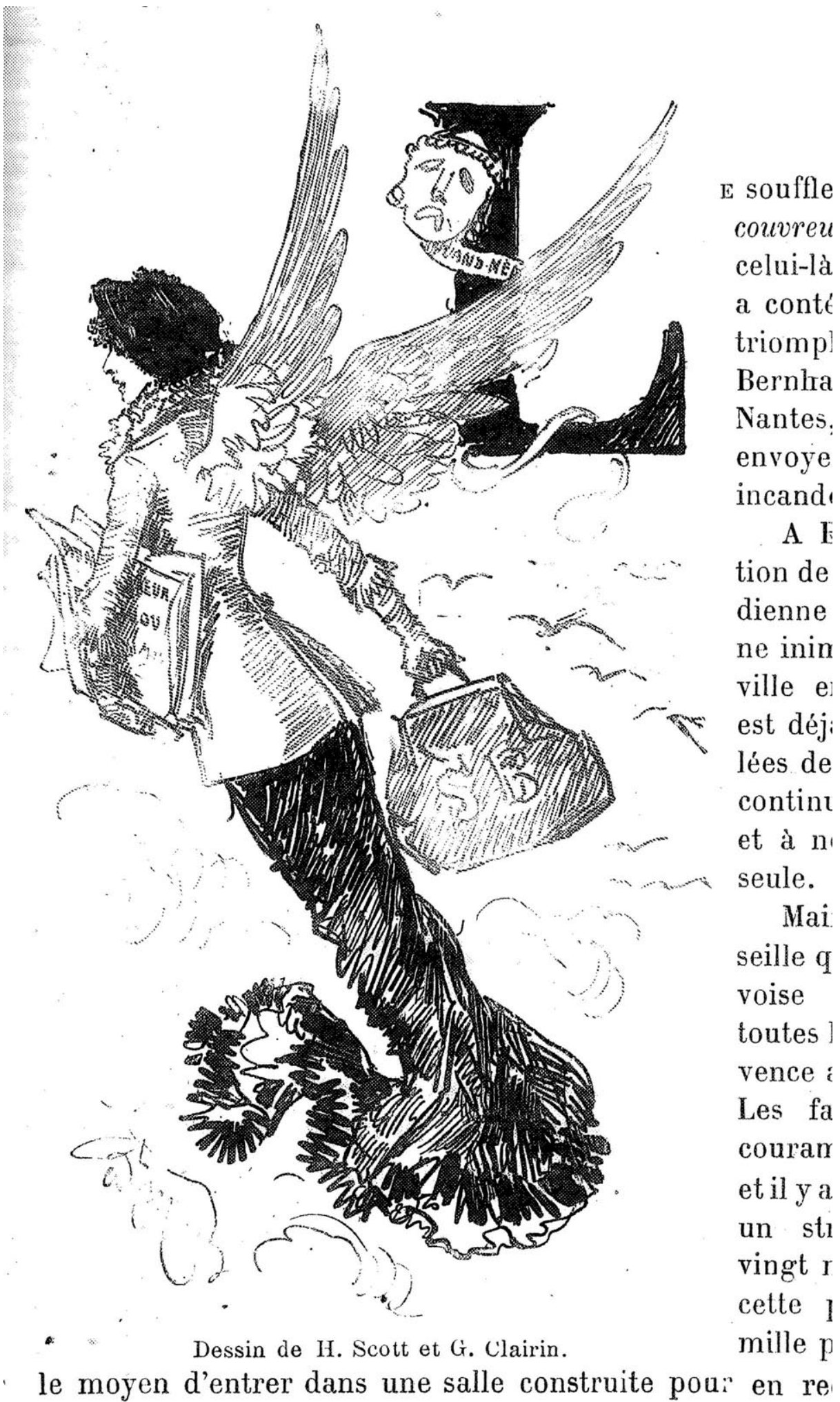




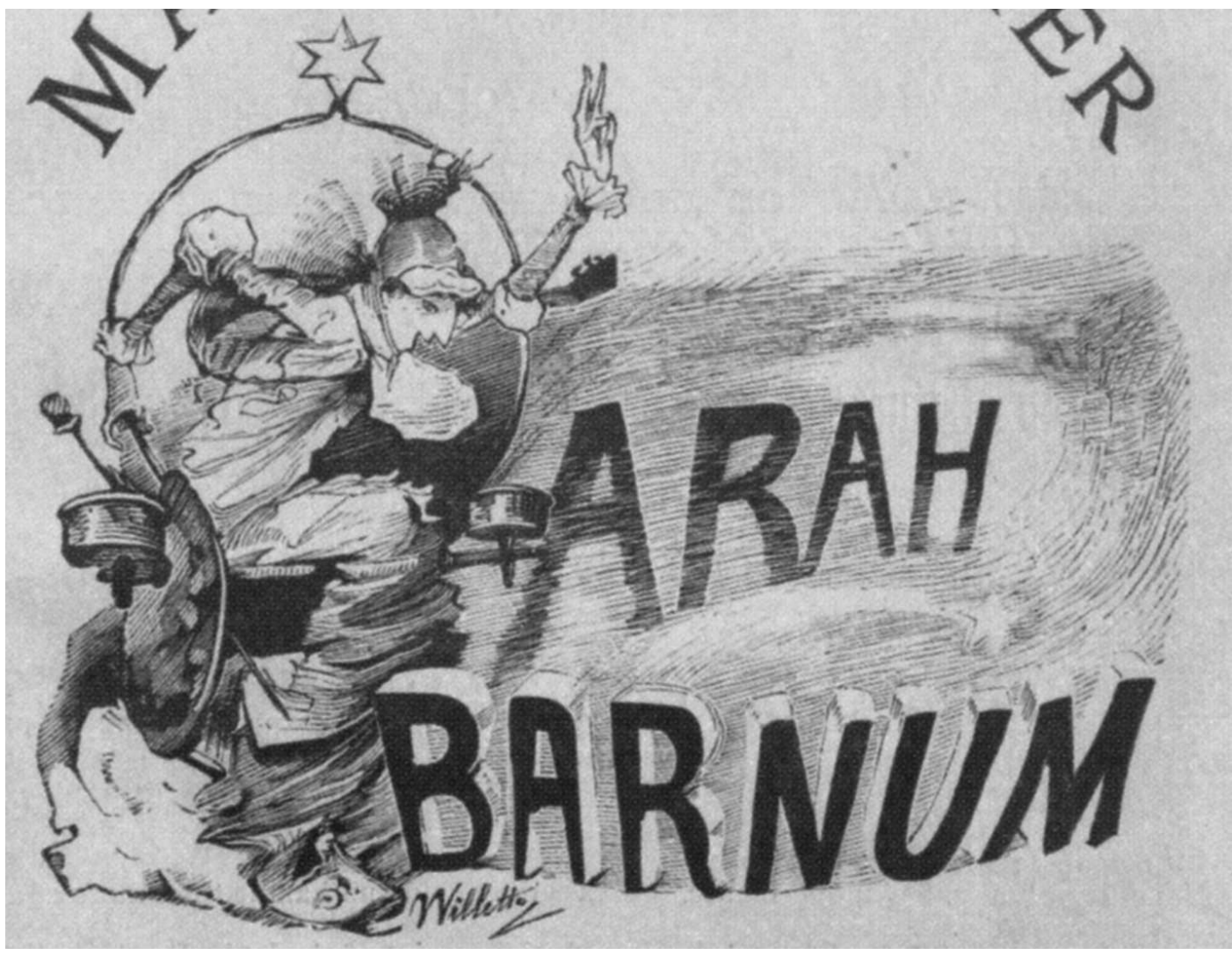

would like to do, describing in long speeches what they are doing, and then narrating at length what they have done that it can read as an antidramatic machine for turning action into description.

Salome is equally engaged, however, with the physical presence that, we have seen, was also crucial to nineteenth-century celebrity. Wilde planned to make Salome an overwhelming sensory experience that would match the expressiveness of its star, using lurid, saturated colors for the set and costumes and releasing scents into the auditorium during the performance (Meisel; Garelick 148). By play's end, the stage is littered with the discarded clothing, blood, and corpses typical of melodrama and boulevard theater. One of the most verbally ornate plays of the nineteenth century, Salome is also one of the most physical, obsessively drawing attention to body parts that Joseph Roach has identi- fied as focal points of the celebrity physique: hair, skin, eyes, and mouth. On the page, the play's blazons seem to fragment the characters and turn them into pure language, but on the stage, those words accentuate the theatrical condition of corporeal presence. The long descriptions Salome offers of Iokanaan's hair and mouth and those other characters give of her eyes and skin are verbal equivalents of the fragmented close-ups that theatergoers obtain using lorgnettes and opera glasses, and characters frequently spotlight the actor's presence onstage from head to toe, as when Herod tells Salome, "Ah! You are going to dance barefoot! That's good!" ("Ah! vous allez danser pieds nus! C'est bien!”; 53; 68).

Throughout, dematerializing similes and metaphoric language give way to physical manifestations. Elaborate figurative speeches often begin and end with blunt assessments of bodies or bold statements of
FIG. 4

Illustration on the title page of Les mémoires de Sarah Barnum, by Marie Colombier, 1883. This unflattering image shows Bernhardt with bony arms, frizzy hair, and an exaggerated hook nose. Crowned by a Jewish star, her body forms an S on the title page of a scandalous mock memoir, written in French by a disgruntled former member of Bernhardt's acting troupe and then translated into English and published in the United States. Courtesy of Carol Ockman and Kenneth E. Silver and of the Laurence Senelick Collection. 
sexual intention: "Your hair is horrible. ... Let me kiss your mouth" "“Tes cheveux sont horribles. . . Laisse-moi baiser ta bouche"; 23-24; 33-34). Salome first likens Iokanaan to "a ray of moonlight, ... . a ray of silver" ("un rayon de lune, ... un rayon d'argent"), but her next simile is more tactile: "His flesh must be very cold, like ivory" ("Sa chair doit être très froide, comme de l'ivoire”; 19; 29). By play's end, she has renounced comparison altogether: "There was nothing in the world as white as your body. There was nothing in the world as black as your hair" ("Il n'y avait rien au monde d'aussi blanc que ton corps. Il n'y avait rien au monde d'aussi noir que tes cheveux"; 65; 82); no longer the basis for endless similes, Iokanaan's body is now incomparable, a cosmic reference point.

The plot similarly moves toward physical contact and wordless action. Salome and the audience first experience Iokanaan as an offstage voice, whose disembodied aural presence stimulates the wish to see him in person: on hearing Iokanaan, Salome immediately wants to see and speak to him (14-15; 23-24). After having him hauled up from the cistern, she wants to "look at him up close" ("le regarde de près"), stating that his "voice intoxicates" her ("Ta voix m'enivre") and that she is "amorous" of his "body" ("amoureuse de ton corps"; 19-21; 29-31). After declaring, "Let me touch your body!" ("Laisse-moi toucher ton corps!"; 22; 32), she aggressively repeats "I will kiss your mouth" ("Je baiserai ta bouche"; 24, 25, 26, and passim; 34, 35, 37, and passim), then does so when presented with his severed head. The dance Salome performs to gain access to Iokanaan is even more physical; nonverbal, it silences even the play's author, who gives only this laconic stage direction: "Salome dances the dance of the seven veils" ("Salomé danse la danse des sept voiles"; 54; 70). As Jessica Simon has argued, this spare verbalization refuses to contain kinetic performance within ekphrastic description; unlike his many predecessors in French literature, Wilde decided not to represent Salome's dance in words, leaving it to the actress playing her to present it in person.

Salome evokes theatrical celebrity not only by combining presence and representation but also by incorporating the nonreciprocity that obtains between fans and celebrities, spectators and actors, into its idiosyncratic form, which transposes the separation of audience and actors in the theater onto the stage itself. The nonreciprocity that defines theater as the distance between actors and spectators becomes a nonreciprocity among the play's characters. Iokanaan spurns Salome, who ignores the Young Syrian, who pays no heed to the pleas of the Page, just as actors pretend not to see spectators, and celebrities exhibit themselves but maintain an aloof distance from the "praying supplicant[s]" craving to communicate with them (Roach 17). On display but untouchable, celebrities can never personally acknowledge all their fans individually; devotees pay to gaze on a star who is dramatically present but rarely returns their look and to whom they cannot speak (Garner 49; Bennett 15). The fan's look is self-annihilating, because it seeks a recognition that it can structurally never receive: fans desire intimacy with the adored celebrity (Dames 44; Blake 168), but the celebrity either ignores them or, by acknowledging them, destroys the gap needed to maintain stardom (Dyer 7; Morin 69-73; Roach 17; Braudy 27, 556).

These asymmetries between actor and spectator, star and fan, surface in Salome as the nonreciprocity of its characters' speeches, desires, and gazes. Part of Salome's notorious strangeness derives from this disjunctive principle; characters repeatedly speak past one another, oblivious to the utterances of their putative interlocutors. Failed acknowledgment structures the play from its opening lines, which function less as dialogue than as parallel monologues that fail to meet (Lew- 
sadder 521); not for this play the dictum that acting is reacting.

YOUNG SYRIAN. How beautiful is the Princess Salome tonight!

HERODIAS'S PAGE. Look at the moon. The moon has a strange air.

LE JeUne Syrien. Comme la princesse Salomé est belle ce soir!

LE PAGE D'hÉRodias. Regardez la lune. La lune a l'air très étrange.

Characters frequently speak about one another in the third person, even when both are onstage, and rarely acknowledge one another's statements and wishes. The Young Syrian pays no heed to the Page's repeated imperative "You must not look at her" ("Il ne faut pas la regarder"; 4; 12); Salome ignores the Young Syrian's many efforts to distract her from Iokanaan, addressing the First and Second Soldiers when he speaks to her $(11-14 ; 20-24)$. She finally speaks to the Young Syrian only to negate his fascination with her by requesting that he bring Iokanaan to her. In exchange, she offers the condescension of a beloved but distant superior: to let a flower fall in his path, to look at him through muslin veils, and "perhaps" to give him a smile $(16 ; 26)$. Such nonreciprocity is the rule in Salome, whose characters repeatedly reject one another's erotic approaches, a refusal of mutuality that the French version underscores by playing with the formal and familiar forms of the second person. Salome, for example, addresses Iokanaan as "tu," an intimacy he usually fails to reciprocate. On the rare occasions that Iokanaan shifts from "vous," he does so only to reject the demand that he return her attention: "Be cursed.... I do not want to look at you. You are cursed" ("Soyez maudite. ... Je ne veux pas te regarder. Tu es maudite"; 26; 37). This familiarity is all contempt. Just as the characters talk past one another, their looks spectacularly fail to coincide. Herodias watches Herod watch Salome; the Page looks at the Syrian, who is "always looking" at Salome ("vous la regardez toujours"; 2; 11), who looks at Iokanaan, who averts his eyes from her. Each character is confined to being audience or actor for another but never both at once.

Idolized by the Young Syrian, Salome idolizes Iokanaan; he is an object of her gaze, attention, and desire, but she is not an object of his. This nonreciprocity only stokes Salome's fandom: she desires that he return her look, even as his refusal to do so only intensifies her obsession with him. Salome crosses over from fan into stalker when she demands Iokanaan's head, an act that manifests the tensions of celebrity: the idol is most alive to the fan when lifeless; stars incite desire, but intimacy undoes stardom. As a sign of the impossible relation between celebrity and fan, we have the decadent pathos of Salome's address to Iokanaan's severed head: "Open your eyes. ... Why do you not look at me?” (“Ouvre tes yeux. ... Pourquoi ne me regardes-tu pas?"; 64; 81). The fan's look can kill the celebrity, as Salome's gaze does Iokanaan, but it can also annihilate the fan; Salome's biggest fan, the Syrian, kills himself when she does not return his gaze, and Salome dies as a fan, when her raving over Iokanaan's head provokes Herod to order her death.

Wilde's play poses questions central to celebrity: whether power comes from looking or showing off, from being seen or withholding oneself from view. Most critics of the play have argued that it equates looking with sexual domination. This is clearly at work: Salome, for example, acquires power over Iokanaan by feasting her eyes on him before and after his death. Linda and Michael Hutcheon have complicated the equation of looking and domination by arguing that in Salome "to look is to grant power to the one observed" and that the title character "is not objectified by the gaze but empowered by it" (16). This formulation cannot account, however, for the fact that Salome enters the stage fleeing Herod's troubling gaze: "I will not 
stay. I cannot stay. Why does the Tetrarch look at me all the while with his mole's eyes under his shaking eyelids?" ("Je ne resterai pas. Je ne peux pas rester. Pourquoi le tétrarque me regarde-t-il toujours avec ses yeux de taupe sous ses paupières tremblantes?"; 10; 18-19). Nor can the claim that being seen empowers Salome explain the play's penultimate lines: "[A ray of moonlight falls on Salome and illumines her.] HEROD. [Turning round and seeing Salome.] Kill that woman!” "(Un rayon de lune tombe sur Salomé et l'éclaire.) HÉRODE (se retournant et voyant Salomé). Tuez cette femme!"). These lines equate visibility with death, but Salome does not die simply from excess visibility, since her execution also coincides with being rendered invisible, blocked from view by the soldiers' shields $(67 ; 84)$. What is at stake in the play's ending is not the sheer fact of being seen but control over one's image; Salome is defeated when she becomes too absorbed by the sight of Iokanaan to manage her own appearance.

Power in Salome thus resides not simply in looking or being looked at but in the exhibition of presence. Salome is most powerful when she can solicit an adoring gaze but keep her audience at a physical distance, which was precisely the power of the theatrical celebrity onstage (and often off it, before the paparazzi era). Salome's exchange with Herod after her dance encapsulates the star's ability to combine deliberate display with an imperious aloofness that averts the risk of degradation inherent in performance. For Herod, Salome's dance is an occasion to deprive her of star power; immediately after her performance, he commands her, "Approach, Salome! Approach so that I can give you your wages. Ah! I pay female dancers well, I do. You, I'll pay you well" ("Approchez, Salomé! Approchez afin que je puisse vous donner votre salaire. Ah! Je paie bien les danseuses, moi. Toi, je te paierai bien"; 54-55; 70). By calling Salome a "danseuse," Herod reduces the princess to the epitome of sexual availability. His repetition of the imperative "Approach" and his shift to the familiar form when he mentions money express the hope that payment will allow the spectator to command intimacy with the performer. Breaching the distance that normally obtains between spectator and star almost immediately causes the spectator great distress, however, for instead of "argent" in the form of money Salome demands "argent" in the form of a silver basin containing Iokanaan's head, an implacable wish that reduces the imperious king to a wheedling bargainer who would rather sacrifice priceless jewels than honor his royal word.

\section{Exemplarity and Impudence}

Having explored the aesthetics of theatrical celebrity in terms of Salome's form, I now turn to the social, political, and religious facets of celebrity that shape the play's content. Scholars of celebrity have often reworked the classical distinction between good fama (truth and honor) and bad fama (rumor and infamy) as a contrast between fame and celebrity. This schema casts fame as genuine, dignified, and permanent renown, linked to masculine virtue and civic deeds, and castigates celebrity as factitious, superficial, and transient, associated with feminine artifice and the shameless public display of actions that should be kept private (Rojek; Inglis). The opposition between fame and celebrity rarely holds in postmodern times, but the few critics to note this have aimed to show that fame is as ephemeral and constructed as celebrity (Baty; Gamson). The reverse, however, also holds true: when the difference between fame and celebrity dissolves, celebrity can incorporate the gravity and influence of fame. For a poet like Walt Whitman, for example, celebrity was fame, because in a democratic society public opinion was the legitimating power (Blake 6). By the nineteenth century, fame had begun to succumb to celebrity, and celebrity was absorbing fame, becoming a 
complex concept that encompassed virtue and vice, representativeness and uniqueness, conformity and transgression (Braudy 344, 388; Rojek 146-48, 179; Roach 8; Blake 56).

The distinction between celebrity and fame became less important in the nineteenth century than the interplay between two kinds of celebrity: a celebrity of exemplarity and a celebrity of impudence, sometimes combined in the same figure. The exemplar typified social virtues, embodied normative values, and consented to being considered a model worthy of imitation. Queen Victoria, a great fan of star performers (Schoch), cultivated a celebrity of exemplarity when she displayed herself as an eminently domestic mother in published accounts of her family vacations, complete with photographs (Homans; Plunkett). By contrast, the impudent showily departed from norms and presented themselves as inimitable, though they often inspired emulation: like Byron, Liszt, and George Sand, Wilde flaunted his difference from the crowd and his indifference to popular opinion and middle-class conventions (Gagnier 51). Such figures were not simply eccentric, a term that implies involuntary uniqueness; the impudent shamelessly chose their differences and elected to exhibit that choice.

The celebrity of impudence marked Wilde up to the end of his career, when he made witty quips during his 1895 trials, and can be traced back to the example set by his mother, Speranza, a well-known feminist and Irish nationalist, who believed that " $\mathrm{t}] \mathrm{h}$ hose who make public opinion ... do not heed it" (Sherard 63). According to a fellow Oxonian, Wilde declared in college, "Somehow I'll be famous, and if not famous, I'll be notorious" (Blair 122); years later, he asked men attending the premiere of Lady Windermere's Fan to wear green carnations, in order to "annoy the public," because, he explained, "it likes to be annoyed" (qtd. in Gagnier 163). When the $S t$ James's Gazette attacked The Picture of Dorian Gray in 1890, Wilde sent a letter to the editor proclaiming imperviousness to public opinion: "I am tired to death of being advertised. I feel no thrill when I see my name in the newspaper. ... I wrote this book entirely for my own pleasure, and it gave me very great pleasure to write it. Whether it becomes popular or not is a matter of absolute indifference to me" "“To the Editor of the St James's Gazette"; 25 June 1890; Holland and Hart-Davis 42829). The paradox of announcing in a letter written for publication in a newspaper that one has no interest in being in the news parallels the paradox embedded in the celebrity of impudence, which is not content simply to challenge social mores but gambles on being rewarded by society for doing so.

Over the course of a career that began in the 1870s and lasted until her death in 1923, Sarah Bernhardt was known for both her impudence and her exemplarity, shifting from one to the other over space and time. Until the 1890 s, she was a controversial figure in France, where the press caricatured her Jewishness and her queer femininity. As we have seen (fig. 4), illustrators in the 1870 s and 1880s pilloried Bernhardt's money-making abilities as Jewish greed, mocked her extreme thinness as ugly and unwomanly, and associated her theatrical and sexual successes with the overweening masculine ambition of a Napoléon (fig. 5). Unfazed, Bernhardt flaunted her status as an unmarried mother whose son bore her surname, announcing herself at social gatherings as "Mademoiselle Sarah Bernhardt et son fils" (Martin 36 ). When she finally married, in 1882 , she caused more scandal by choosing a younger man. For years the French media resented her for attaining stardom abroad and quitting the Comédie Française in 1880, but outside France she came to represent the glories of its language and culture. By the 1890s even the French press had begun to laud her as a national ambassador and artistic genius, and in the early twentieth century, after becoming a grandmother, undergoing a partial leg 


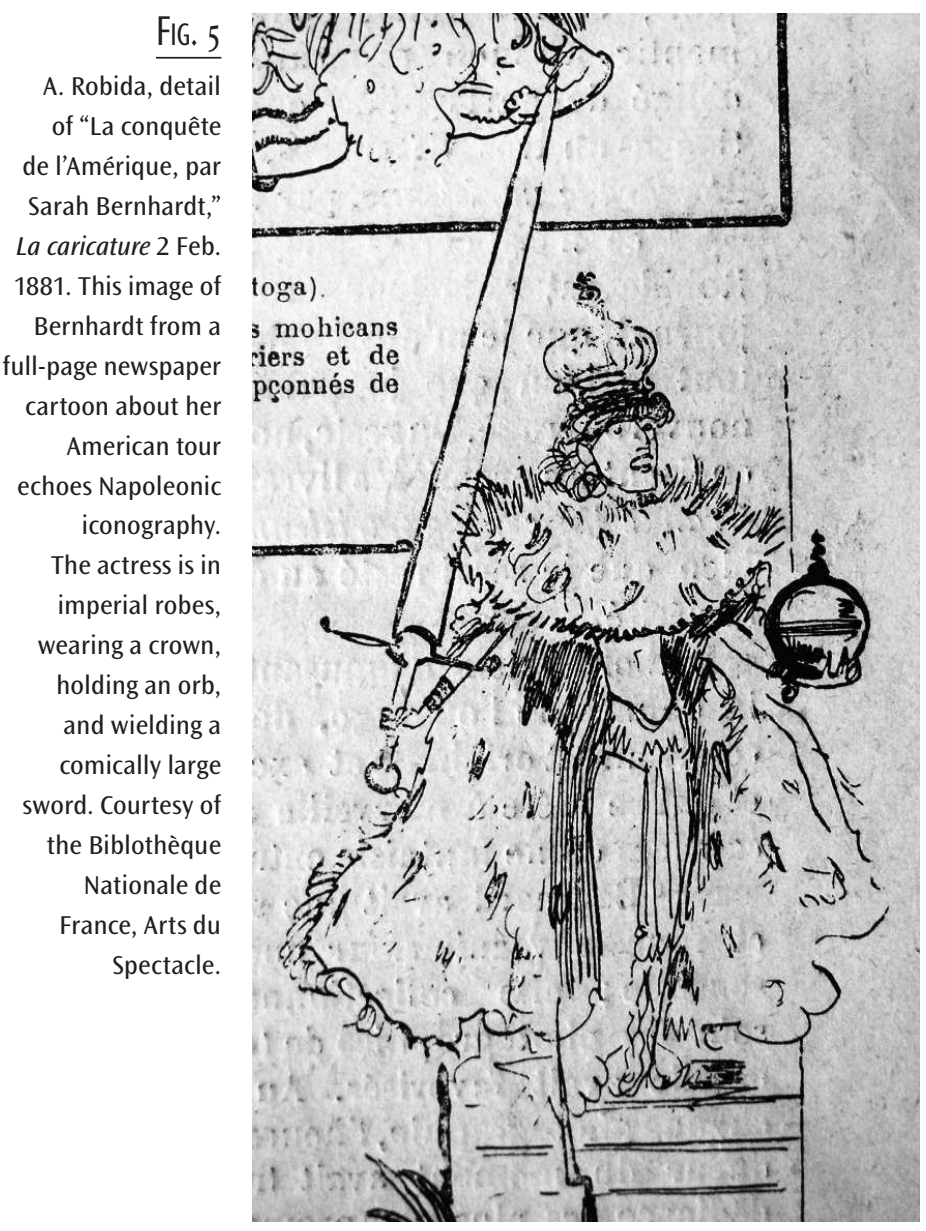

amputation, and entertaining French soldiers during World War I, she became an exemplary figure of patriotic womanhood (Silver).

In 1892, when Bernhardt agreed to play Salome, her celebrity image blended exemplarity and impudence. She was lauded for being "conventionality defied and originality expressed. . . . Far beyond the majority of mortals she has found it possible to disregard limitations, and do pretty much as she wished" (Vassault 576). The press revered her as a tragic actress who represented all that was "universal" (Case), but it also fastened on the singularity and rebelliousness associated with her penchants for exotic pets, sleeping in a coffin, and challenging pieties while charming the public. Anecdotes about Bernhardt's ripostes to gender regulation and to moral judgments proliferated. Asked what "attributes women love in men," she replied, "Those of women" ("Sarah Bernhardt's Idea”). When the very proper Madge Kendal congratulated Bernhardt on a fine performance but added, "It is a pity, madame, that your plays always deal with passion, so that I cannot take my young daughters to see them," Bernhardt retorted, "Ah, madame, you should remember that were it not for passion you would have no daughters to bring" (Marbury 145). In 1879 the actress wrote to a Protestant minister who had denounced her, "My dear confrère, Why attack me so violently? Actors ought not to be hard on one another," then published her letter in a newspaper (Huret 91). Bernhardt herself articulated the principle underlying the celebrity of impudence in an 1879 interview on how to garner fame: "Humour them, conform to the tradition, and you may win some admiration. Dare to disregard it, and bear the chill of their temporary disfavour, and you will win all" (qtd. in Stokes 32). One way to please the middle-class mass public, which conferred celebrity, was to stand apart from it and demonstrate indifference to its opinion.

Bernhardt's famously seductive contempt for norms and authorities amplified her resonance as a casting choice for Salome, a willful adolescent (Kaye) who insolently disobeys her parents, performs the scandalous dance of the seven veils, and attempts to seduce a saint, then demands his head for her "own pleasure" ("propre plaisir"; 56; 71). Where Bernhardt combined impudence with exemplarity, Salome evacuates exemplarity completely from the scene, becoming what the censor called, more aptly than he perhaps realized, a "miracle of impudence" (qtd. in Lewsadder 525). Royal and religious figures are typically exemplary characters, but in Wilde's play their endless conflicts prevent them from incarnating standards. Salome's mother, Herodias, accuses her husband, the king, of lacking royal blood and mocks Herod's cowardice $(34 ; 46)$, crowing, "The 
kings of the earth are afraid" ("Les rois de la terre ont peur"; 53; 69); in turn, he calls her a liar $(33 ; 44)$, casting doubt on the royal word.

Throughout the play, saints, prophets, rabbis, and monarchs charge one another with defying the law, then denounce such denunciations as themselves insolent. Iokanaan upbraids the queen and princess for being shameless, "impudique" $(42 ; 54)$, but his exotic name aligns him with the characters he excoriates, and his rhetoric and diction echo those of Salome, whom he reviles. He is also an outlaw, his moral supremacy denied by Herodias, who labels his challenges to her royal authority "infâme" $(42 ; 55)$ - not only infamous but slanderous, operating by inflammatory innuendo. Herodias's word choice also underscores Iokanaan's theatricality, for infâme was the technical term for actors' legal status before the French Revolution finally granted performers rights to marry and receive religious burial (Maslan 19). Steeped in scandal, the play generates serial accusations of infamy that are themselves bound up in shameless, insubstantial claims to authority. In Salome, nothing is sacred.

\section{Celebrity as the Democratization of Religion and Monarchy}

Wilde wrote Salome at the end of a century whose increasing democratization spurred people to theorize religion and royalty using the same concepts underlying celebrity: expressive individualism, the social body, democratic choice, and mass diversion. David Strauss and Ernest Renan personalized Jesus by making him a historical, biographical figure; Ludwig Feuerbach redefined deities as projections of the human ideal of "personality itself" (153); and Émile Durkheim considered gods expressions of what human beings valued most, their social bonds with one another (Roach 18). Walter Bagehot recast the British monarchy as a popular spectacle, deprived of real power but useful as an entertaining dis- traction and national tradition (Roach 60). For centuries fame had been a privilege of hereditary caste, priestly status, and poetic genius; absolute monarchs and religious institutions had monopolized pageantry and strictly controlled the stage (Braudy 315-20). In the nineteenth century, by contrast, celebrity and its theatrical powers could belong to anyone willing to acknowledge the authority of the populace, which during the French Revolution had proved itself capable of using direct action to make and break gods, rulers, and theatrical performances (Maslan). Democratization intensified what had often been close ties between theater and religion (Knapp), and by the late nineteenth century divinity and government had come to depend, like celebrity, on media representation and public opinion. As increasingly large and heterogeneous groups legitimated religious and political leaders (Blake 47), monarchs and popes retained power only by consenting to be stars, and celebrities became gods (Morin 32, 54, 100; Braudy 28; Gitlin 81; Baty 20; Rojek 9, 74-77; Roach 17, 153-54).

Populist, commercial, and participatory, nineteenth-century theater molded the populace but was also subject to it, thus challenging the religious monopoly on shaping values as well as the unilateral, antidemocratic way that most sects exercised moral suasion. Alexis de Tocqueville observed that "[p]lays ... represent, even among aristocratic nations, the most democratic element of their literature" (567), and in 1880 Oscar Wilde wrote, "... I am working at dramatic art because it's the democratic art, and I want fame ..." (“To E. F. S. Pigott”; Sept. 1880; Holland and Hart-Davis 98). Tellingly, Wilde defined fame as celebrity-not as providing deep and lasting pleasure to the discerning few but as attracting the attention of the many. Ironically, he made this observation in a letter accompanying a copy of Vera, one of his few theatrical flops, and addressed to none other than E. F. S. Pigott, who would later 
deny Salome a license for performance. Pigott's decision underscored that even in 1892 the struggle among democracy, religion, and royalty was far from over. The office of the lord chamberlain was part of the royal household and still enforcing a Reformation ban on depicting biblical characters onstage, instituted when the English state absorbed the church. Such laws originally aimed to delegitimize Catholicism's theatrical approach to religion, but by the nineteenth century they had become ways to protect religion from theater's profaning democracy and to prevent blasphemous views from gaining public influence.

Democratization similarly converted royalty into a form of celebrity, thus making it easier for celebrities to approximate royalty. Describing his 1882 tour of the United States, which resembled those of Sarah Bernhardt the year before and of the Prince of Wales in 1860 , Wilde comically played up how publicity had elevated him: "I . . . am now treated like the Royal Boy. . . I I stand at the top of the reception rooms ... bow graciously and sometimes honour them with a royal observation, which appears next day in all the newspapers. ... Loving virtuous obscurity as much as I do, you can judge how much I dislike this lionising, which is worse than that given to Sarah Bernhardt I hear" ("To Mrs George Lewis"; c. 15 Jan. 1882; Holland and Hart-Davis 126). Wilde could archly claim equivalence with the Prince of Wales and supremacy over Bernhardt because, like them, he was now a celebrity. To be treated like royalty was not to be given political power or aristocratic titles but to have one's sayings reported in the newspapers.

In a democratic age, however, when divinity and royalty were no longer sacred, to be called divine or imperial could not protect celebrities from calumny-just as the monarchs and saints of Salome have no immunity from insult. Bernhardt was dubbed "the divine Sarah" and often hailed as a queen, not least because she played so many onstage, but, like modern sovereigns, she was a target of derision as well as of accolades, subject to public exposure and to popular judgment. The story went that when Bernhardt complained to the Prince of Wales about malicious press coverage, he consoled her by saying, "[Y]ou are not nearly so badly spoken of as my mother" (All 15). As Wilde experienced during his trials, celebrities, like royalty, could be demonized as readily as they were acclaimed.

Salome incorporates the conflict that led to its censorship, over who owns religion and has the right to determine how others will present sacred figures such as gods, saints, and monarchs. In refusing Wilde's play a license for public performance, the lord chamberlain's office objected both to the portrayal of biblical figures onstage and to how Wilde portrayed them: as carnal objects of erotic desire whose physical attributes are often described through biblical citations that adapt "scriptural phraseology to situations the reverse of sacred" ("Books"). One can see the censor's point; when Iokanaan urges Salome to seek out Jesus, she asks, "Is he as beautiful as you are?" ("Est-il aussi beau que toi?"; 21; 31). Salome goes further, depicting both royalty and religion as ephemeral and disposable, the results of human creation and thus vulnerable to human destruction. Neither kings nor gods rule absolutely in Salome, not least because they are at war with each other. As we have seen, the royal family is riven by infighting and its legitimacy questioned, while lengthy doctrinal quarrels among Jewish sects, whose centrality often puzzles readers, establish a situation in which religious beliefs are subject to debate. Herod is king, but he has a "master" ("maître"), Caesar, who must share the title "Savior of the world" ("Sauveur du monde") with Jesus, leaving it doubtful that either wields the power the epithet implies (36-37; 49-50). Similarly, characters refer to both Herod and Christ as "Seigneur"; that two such disparate charac- 
ters share a title to supremacy indicates how relative power is in this play's universe.

Recurrent motifs of regicide and deicide, rarely remarked by critics, further undermine the autarchy of monarchy and religion. Characters frequently mention kings and gods withering at the pleasure of the populace or dying at one another's hands. Early in the play, one character explains to another that the Romans chased his deities away and that when he went to look for them he could not find them: "I think they are dead" ("Je pense qu'ils sonts morts"; 5 ; 13). Just as there are many gods, there are many monarchs, all expendable mere mortals. We learn from Herod that the Young Syrian is a hostage, his father a king chased by Herod from his kingdom, his mother a queen whom Herodias enslaved $(30 ; 42)$. Iokanaan calls for Queen Herodias's death: "Bring a multitude of men against her. Let the people take stones and stone her" ("Faites venir contre elle une multitude d'hommes. Que le peuple prenne des pierres et la lapide....."; 42; 54 [ellipsis in orig.]). When the Cappadocian remarks that "it is a terrible thing to strangle a king," the First Soldier replies, "Why? Kings have only one neck, like other men" ("c'est terrible d'étrangler un roi ... Pourquoi? Les rois n'ont qu'un cou, comme les autres hommes"; 9; 18), referring to Herod's execution of the former ruler, his elder brother.

As we saw earlier, the rhetoric of scandal attenuates royal prestige throughout the play. Conversely, religion thrives in Salome as a matter of the visible and through publicity and report. Several extended dialogues highlight the conflict between Jews, who "worship a God that one cannot see" ("adorent un Dieu qu'on ne peut pas voir"; 5 ; 13), and those who adore a god they can see and touch. Herod notes of Iokanaan, "He is a man who has seen God" ("C'est un homme qui a vu Dieu"; 34; 46); other characters remark that, as a result, a cult has coalesced around him. Salome never names Jesus or puts him onstage, but characters speak of him as human enough to be sighted (38-41; 50-54), their accounts of his miracles framed as the chatter of rumor: "they say he's in Samaria at present" ("On dit qu'il est en Samarie à présent"; 41; 53); "he was seen by a crowd of people" ("Il a été vu par une foule de personnes"); "people who were there told me about it" ("Des personnes qui étaient là me l'ont dit”; 38-39; 51).

Iokanaan's vivid speeches about Jesus function, like publicity, to provoke interest in a figure still little known in the world of the play, most of whose characters do not accept him as divine. In Christian iconography, John the Baptist is a publicist for Jesus, announcing the news of his divinity on a scroll that declares "Behold the Lamb of God." Wilde presents Iokanaan as both impresario and groupie, a publicist who creates fans and is also the supreme fan. As a disciple, Iokanaan fulfills the fan's functions of worshipping and talking about the celebrity; as Jesus's intimate, Iokanaan enjoys his own vicarious celebrity, attracting a crowd of followers because of his eccentric habits, bizarre clothing, and proximity to Jesus Christ, superstar. As the First Soldier says of Iokanaan, "An enormous crowd used to follow him. He even had disciples" ("Une grande foule le suivait. Il avait même des disciples"; 7; 15). The French word Wilde uses, "foule," links Iokanaan's followers to a particularly modern form of public, teeming with democratic desires to pull down and mingle with their rulers and divinities (Garelick 132).

The ultimate representative of the power of the public and the celebrities it creates is Salome, who thwarts the king by requesting that he cut Iokanaan down to size, thus eliminating the only person onstage whose star power rivals her own. Salome's dance allows her to demand " $t$ ] he head of Iokanaan" ("[l]a tête d'Iokanaan"; 58; 74); her performance licenses her domination of both king and holy man. After exhorting the executioner to "[s]trike, strike, ... [s]trike" ("[f]rappe, 
frappe, ... [f]rappe"; 63; 80), Salome addresses a vengeful tirade to Iokanaan's bloody, severed head, reveling in her triumph over him: "I will kiss your mouth, Iokanaan. ... I still live, but you, you are dead, and your head belongs to me. I can do what I want with it" (“je baiserai ta bouche, Iokanaan. ... [M]oi je vis encore, mais toi tu es mort et ta tête m'appartient. Je puis en faire ce que je veux"; 64; 81). Salome is an imperious star performer and scandalous princess who will herself soon die, but she also occupies the role of an unruly public, defying a king to obtain a saint's head on a silver platter, a sanguinary, sacrilegious demand that aligns her with the revolutionary crowds who applauded the use of the guillotine to subject royalty and religion to their demotic power.

\section{The Author and the Actress}

Salome is performer and spectator, idol and fan, star and stalker; her name and the play's title encapsulate the link between celebrity and fandom, the connections between proximity and distance, interdependence and nonreciprocity. Wilde's career suggests a similarly tensile bond between the author, master of representation, and the actress, queen of presence. As his exclamation over Bernhardt's decision to play Salome shows, Wilde enjoyed the vicarious publicity conferred by association with a celebrity performer. In an 1882 letter to the actress Mary Anderson, he defined drama as a collaboration between representation and presence: "All good plays are a combination of the dream of a poet and that practical knowledge of the actor which ... for poetic effect, which is description, substitutes dramatic effect, which is Life" ("To Mary Anderson"; early Sept. 1882; Holland and HartDavis 178-79). In 1888 Wilde averred "it was not until I heard Sarah Bernhardt in Phèdre that I absolutely realized the sweetness of the music of Racine" ("Literary and Other Notes III" 109). In statements such as these, Wilde cast the actress as Pygmalion and the author's text as Galatea, completely realized only by the performer's final, vivifying touch.

Wilde also valued the autonomy of the poet, however, and on occasion asserted the supremacy of authors and the uselessness of actors, claiming to prefer puppets. $\mathrm{He}$ famously insisted that he had not written $\mathrm{Sa}$ lome for Bernhardt: "I have never written a play for any actor or actress, nor shall I ever do so. Such work is for the artisan in literature, not for the artist" ("To the Editor of The Times"; c. 1 Mar. 1893; Holland and HartDavis 559). In an 1892 interview, he praised Bernhardt, describing his pleasure at hearing "my own words spoken by the most beautiful voice in the world" during rehearsals ("Censure"), but his phrase tellingly avoided naming her. At the height of his career as an author, Wilde saw himself as writing only for himself and therefore owning his text ("my own words"). The performer is subtly secondary, reduced to a "voice," which, no matter how supremely beautiful, speaks the words of an author who underscores that he is not the star's servant and did not produce them with her in mind.

Earlier in his career, when Wilde was better known as a celebrity than as an author, he was happy to hitch his wagon to Bernhardt's star. Since Jean-Jacques Rousseau, writers had been minor celebrities, and in the Victorian era Victor Hugo, Charles Dickens, and Ralph Waldo Emerson achieved fame as heroes and sages. Wilde, however, was a new type: the author as feminized celebrity personality-as actress. One of the earliest caricatures of Wilde, an 1881 image by J. B. B. Nichols, portrays him with long hair and full lips, in aesthetic white costume, holding a branch of lilies, the words "HOW UTTER" floating around his knees (fig. 6). In the border of the image, idealized muses and cupids alternate with recognizable images of real actresses, including Ellen Terry, Lillie Langtry, and, directly above Wilde, Sarah Bernhardt. The im- 


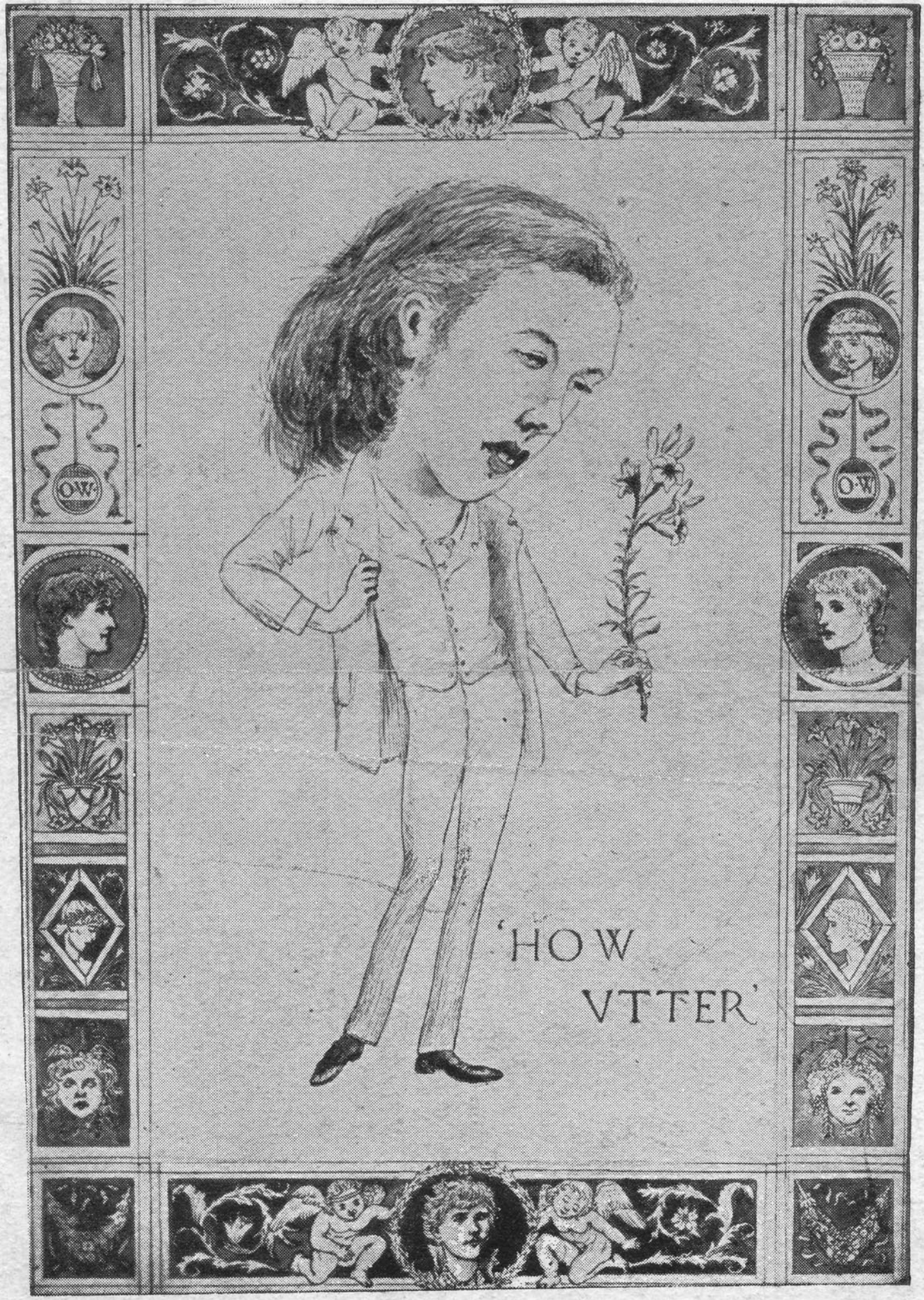

FIG. 6

J. B. B. Nichols, How Utter, 1881. Wilde is framed by famous actresses of the day, including Bernhardt, at the top. Courtesy of the Clark Library, UCLA. 
age presents Wilde as the actresses' fan, muse, and author, but it also makes him an aspiring member of a dramatic sorority. He is superior to the actresses in scale but inferior in the degree of dignity conferred on his image; he is above and beneath them, dwarfs them and is outnumbered by them. ${ }^{5}$

Wilde embraced the theatrical celebrity that such images attributed to him. He was a fan of actors and actresses, a playwright committed to writing crowd-pleasing comedies, and a theorist of the self as a work of art. Known as a "great admirer" of Bernhardt (Massett), Wilde capitalized on her successful London debut in the summer of 1879 by publishing a sonnet entitled "To Sarah Bernhardt" in the newspaper the World on 11 June 1879, thus balancing a high art form with the speedy tempo of a commercial tiein; in the 1881 book edition of his poems, he gave the work a more literary and less topical title, "Phèdre." In her autobiography, Bernhardt vaunted that Wilde was there to greet her, bearing "an armful of lilies," when she disembarked in England to begin her 1879 tour, thus situating the author, ten years her junior, as the actress's adoring fan (310). In 1882 he turned the stance of imitative follower into a celebrity of his own when he toured the United States and Canada one year after Bernhardt had. Wilde liked to credit Bernhardt with suggesting that he undertake the tour, although the idea probably came from a newspaper publisher, Mrs. Frank Leslie (Holland and Hart-Davis 123), and he prepared for his public appearances by taking elocution lessons from the actor Hermann Vezin (Holland and Hart-Davis 99). Once in America, he followed Bernhardt's itinerary, staying at hotels she had visited and sitting for Napoleon Sarony, who had photographed Bernhardt the year before. In the 1890s, an etching of a Bernhardt portrait, inscribed by "the great tragedienne," hung in the Wildes' aesthetically decorated and much publicized house ("Mrs. Oscar Wilde" 93).
Wilde attained celebrity as an author by emulating an actress, while Bernhardt secured theatrical stardom by taking authorial control over her image, roles, and career (Stokes). Though the actress was known for riding roughshod over writers, and the author often wanted to dictate to performers, they were not simply in conflict but also in cooperation and identification-a mutual admiration society. Such incorporation is part of the celebrity process, which demands that performers script themselves and that authors put themselves on display. After returning to Britain in 1882, Wilde vaunted the links between his American tour and Bernhardt's, even claiming that he had agreed to wear an oilskin costume at Niagara Falls "only when he was informed that such a great artist as Mdlle Sarah Bernhardt had [also] worn a dress of that kind" ("Mr. Oscar Wilde"). Years later, in December 1898, Wilde went "to see my dear Sarah in La Tosca" ("To Frank Harris"; 29 Dec. 1898); after the show he wrote, "I went round to see Sarah and she embraced me and wept, and I wept, and the whole evening was wonderful” ("To Robert Ross"; 2 Jan. 1899; Holland and Hart-Davis 1115-16). Wilde and Bernhardt now both lie in Père Lachaise Cemetery, in graves that register their indelible absence and their ongoing presence, still assiduously attended by fans acting out and carrying on the drama of celebrity.

\section{NOTES}

I thank James Eli Adams, Ellis Avery, Joseph Allen Boone, Jean Howard, Shannon Jackson, Eleanor Johnson, Jeffrey Knapp, Martin Puchner, Nancy Vickers, and others too numerous to name for their generous, incisive comments on versions of this essay.

1. The quotations in English from Salome are my translations of Wilde's original French text, published simultaneously in France and England in 1893. Almost all my translations differ from those of Alfred Douglas, 
who is credited with the English translation published in 1894 that has become the standard English edition and is widely available in a Dover facsimile reprint. For the convenience of readers who use that edition, the first of the two page numbers that follow mentions of Wilde's play refers to Douglas's translation; the second page number refers to the 1893 French edition, available in a 2008 facsimile reprint from Presses Universitaires de France.

2. Previous critics have related the play's emphasis on the gaze and on desire to gender and sexuality (Dijkstra; Dellamora; Gagnier; Garelick; Donohue; Lewsadder). Several critics have read Salome as a camp take on celebrity, arguing that Wilde uses irony, reversal, and excess to unsettle the audience and alienate it from commodity culture (Gagnier 165-66; Garelick 13, 146; Powell, Oscar Wilde 52 ). I would argue that the camp reading oversimplifies celebrity culture and overestimates Wilde's distance from it.

3. Dyer claims that celebrity ideologically resolves irreconcilable beliefs (36); Roach describes stardom as a "precarious balance between ... mutually exclusive alternatives" (8). I would modify these claims in two ways. First, the celebrity unites alternatives and beliefs that are neither irreconcilable nor mutually exclusive but dialectically entwined. Second, celebrity is neither stabilizing nor teetering but dynamic; it dramatizes the production of mobile selves and plastic social relations.

4. Wilde was the subject of a "Bijou Portrait" in Society on 21 Mar. 1885, Bernhardt on 8 Dec. 1883.

5. On Wilde's relation to the figure of the actress, see Powell, "Verdict," although in my view Powell overstates Wilde's hostility to female performers.

\section{Works CiTED}

Many of the newspaper articles cited below are located in the Harvard Theatre Collection's boxes of Sarah Bernhardt material (HT), the Victoria and Albert Theatre Collection of "Personal Boxes" for Sarah Bernhardt (VA), and the Clark Memorial Library collection of Wildeiana (CL). In these collections, materials exist as clippings often shorn of page numbers and dates. I have used abbreviations to give the archival provenance of articles lacking such identifying information.

All about Sarah "Barnum" Bernhardt: Her Loveys, Her Doveys, Her Capers and Her Funniments. London: Williams, 1884. Print.

Auslander, Philip. Liveness: Performance in a Mediatized Culture. London: Routledge, 1999. Print.

Baty, S. Paige. American Monroe: The Making of a Body Politic. Berkeley: U of California P, 1995. Print.

Benjamin, Walter. "The Work of Art in the Age of Mechanical Reproduction." Illuminations: Essays and Reflections. Ed. Hannah Arendt. Trans. Harry Zohn. New York: Schocken, 1968. 217-51. Print.
Bennett, Susan. Theatre Audiences: A Theory of Production and Perception. 2nd ed. London: Routledge, 1997. Print.

Bernhardt, Sarah. Memories of My Life: Being My Personal, Professional, and Social Recollections as Woman and Artist. New York: Appleton, 1907. Print.

Blair, David Hunter. In Victorian Days. 1939. London: Longmans, 1969. Print.

Blake, David. Walt Whitman and the Culture of American Celebrity. New Haven: Yale UP, 2006. Print.

"Books of the Week." London Times 23 Feb. 1893: 8. Print.

Braudy, Leo. The Frenzy of Renown: Fame and Its History. New York: Oxford UP, 1986. Print.

Bristow, Joseph. Introduction. Bristow, Oscar Wilde 1-45. —_ ed. Oscar Wilde and Modern Culture: The Making of a Legend. Athens: Ohio UP, 2008. Print.

Busson, Dani. Sarah Bernhardt. Paris: Fischer, n.d. [c. 1912]. Print.

Case, Jules. “La fille à Blanchard.” La plume 1 Jan. 1901: 20. Print.

Dames, Nicholas. "Brushes with Fame: Thackeray and the Work of Celebrity." Nineteenth-Century Literature 56.1 (2001): 23-51. Print.

"Days with Celebrities." 1883. Print. CL, Wilde Portfolio Case.

Dellamora, Richard. "Traversing the Feminine in Oscar Wilde's Salomé." Victorian Sages and Cultural Discourse: Renegotiating Gender and Power. Ed. Thaïs E. Morgan. New Brunswick: Rutgers UP, 1990: 246-64. Print.

Dijkstra, Bram. Idols of Perversity: Fantasies of Feminine Evil in Fin-de-Siècle Culture. New York: Oxford UP, 1988. Print.

Donohue, Joseph. "Distance, Death and Desire in Salome." Raby 143-60.

Douglas, Lord Alfred, trans. Salome. By Oscar Wilde. London: Elkin Mathews and John Lane, 1894. New York: Dover, 1967. Print.

Dyer, Richard. Stars. 1979. London: BFI, 1986. Print.

"Entr'acte: Bernhardt and Advertising." Sarah Bernhardt: The Art of High Drama. Ockman and Silver 144-47.

Feuerbach, Ludwig. The Essence of Christianity. 1841. Trans. George Eliot. Amherst: Prometheus, 1989. Print.

Fourcaud. "Le théâtre." Rev. of Fédora, by Victorien Sardou. Vaudeville, Paris. La vie moderne Jan. 1883 11-12. Print.

Gagnier, Regenia. Idylls of the Marketplace: Oscar Wilde and the Victorian Public. Stanford: Stanford UP, 1986. Print.

Gamson, Joshua. Claims to Fame: Celebrity in Contemporary America. Berkeley: U of California P, 1994. Print.

Garelick, Rhonda K. Rising Star: Dandyism, Gender, and Performance in the Fin de Siècle. Princeton: Princeton UP, 1998. Print. 
Garner, Stanton B. Bodied Spaces: Phenomenology and Performance in Contemporary Drama. Ithaca: Cornell UP, 1994. Print.

Gilman, Sander L. "Salome, Syphilis, Sarah Bernhardt, and the Modern Jewess." The Jew in the Text: Modernity and the Construction of Identity. Ed. Linda Nochlin and Tamar Garb. London: Thames, 1996. 97-120. Print.

Gitlin, Todd. "The Culture of Celebrity." Dissent 45.3 (1998): 81-83. Print.

Guénoun, Denis. Actions et acteurs. Raisons du drame sur scène. Paris: Belin, 2005. Print.

Guibert, Noëlle. Portrait(s) de Sarah Bernhardt. Paris: BNF, 2000. Print.

Hart, F. Elizabeth. "Performance, Phenomenology, and the Cognitive Turn." Performance and Cognition: Theatre Studies and the Cognitive Turn. Ed. Bruce McConachie and Hart. London: Routledge, 2006. 29-51. Print.

Holland, Merlin, and Rupert Hart-Davis, eds. The Complete Letters of Oscar Wilde. New York: Henry Holt, 2000. Print.

Homans, Margaret. Royal Representations: Queen Victoria and British Culture, 1837-1876. Chicago: U of Chicago P, 1998. Print.

Houssaye, Arsène. "Opinions." Revue encyclopédique 15 Dec. 1893: 1267. Print.

Huret, Jules. Sarah Bernhardt. London: Chapman, 1899. Print.

Hutcheon, Linda, and Michael Hutcheon. "Here's Lookin' at You, Kid': The Empowering Gaze in $\mathrm{Sa}$ lome." Profession (1998): 11-22. Print.

"The Idol-Woman and the Other." Times [London] 28 Mar. 1923. Print. VA.

Inglis, Fred. A Short History of Celebrity. Princeton: Princeton UP, 2010. Print.

Kaplan, Joel. "Wilde on the Stage." Raby 249-75.

Kaye, Richard. “Salome's Lost Childhood: Wilde's Daughter of Sodom, Jugendstil Culture, and the Queer Afterlife of a Decadent Myth." The Nineteenth-Century Child and Consumer Culture. Ed. Denis Denisoff. Aldershot: Ashgate, 2008. 119-34. Print.

Knapp, Jeffrey. Shakespeare's Tribe: Church, Nation, and Theater in Renaissance England. Chicago: U of Chicago P, 2002. Print.

Lewsadder, Matthew. "Removing the Veils: Censorship, Female Sexuality, and Oscar Wilde's Salome.” Modern Drama 45.4 (2002): 519-44. Print.

London and Provincial Press Opinions: Madame Sarah Bernhardt and Company at the London Coliseum. N.p.: n.p., 1910. Print. VA.

Marbury, Elisabeth. "My Crystal Ball." Saturday Evening Post 15 Sept. 1923: 24+. Print.

Martin, Theodore. Essays on the Drama: Second Series. London: n.p., 1879. Print.
Maslan, Susan. Revolutionary Acts: Theater, Democracy, and the French Revolution. Baltimore: Johns Hopkins UP, 2005. Print.

Massett, Stephen. Letter to Oscar Wilde. 9 Jan. 1891. MS. CL.

McKenna, Neil. The Secret Life of Oscar Wilde. New York: Basic, 2006. Print.

Meisel, Martin. "The World, the Flesh, and Oscar Wilde: Body Politics in Salome and Dorian Gray." NineteenthCentury Contexts 16.2 (1992): 121-34. Print.

Mills, C. Wright. The Power Elite. New York: Oxford UP, 1959. Print.

Morin, Edgar. Les stars. Paris: Seuil, 1957. Print.

“Mr. Oscar Wilde on America." Freeman's Journal 11 July 1883. Print. CL 10.18A.

“Mrs. Oscar Wilde at Home." To-day 24 Nov. 1894: $93-$ 94. Print. CL, Wildeiana box 7B.

North, Michael. "The Picture of Oscar Wilde." PMLA 125.1 (2010): 185-91. Print.

Novak, Daniel A. "Sexuality in the Age of Technological Reproducibility: Oscar Wilde, Photography, and Identity." Bristow, Oscar Wilde 63-95.

Ockman, Carol. "Was She Magnificent? Sarah Bernhardt's Reach." Ockman and Silver 23-73.

Ockman, Carol, and Kenneth E. Silver, eds. Sarah Bernhardt: The Art of High Drama. New York: Jewish Museum; New Haven: Yale UP, 2005. Print.

Oscar Wilde's Visit to America. Boston, 1882. Print. CL, box 7B.68.

Picon, Sophie-Aude. Sarah Bernhardt. Paris: Gallimard, 2010. Print

Plunkett, John. Queen Victoria: First Media Monarch New York: Oxford UP, 2003. Print.

Powell, Kerry. Oscar Wilde and the Theatre of the 1890s. Cambridge: Cambridge UP, 1990. Print.

. "A Verdict of Death: Oscar Wilde, Actresses, and Victorian Women." Raby 181-94

Puchner, Martin. Stage Fright: Modernism, Antitheatricality, and Drama. Baltimore: Johns Hopkins UP, 2002. Print.

Raafat, Z. "The Literary Indebtedness of Wilde's Salomé to Sardou's Théodora." Revue de littérature comparée 40 (1966): 453-66. Print

Raby, Peter. The Cambridge Companion to Oscar Wilde. Cambridge: Cambridge UP, 1997. Print.

Roach, Joseph. It. Ann Arbor: U of Michigan P, 2007. Print

Rojek, Chris. Celebrity. London: Reaktion, 2001. Print.

"Sarah Bernhardt's Idea." Sunday newspaper published in Albany. Print. HT, box 2.

Schickel, Richard. Intimate Strangers: The Culture of Celebrity. New York: Doubleday, 1985. Print.

Schoch, Richard. Queen Victoria and the Theatre of Her Age. Basingstoke: Palgrave, 2004. Print. 
Sherard, Robert. The Real Oscar Wilde. London: Laurie, 1916. Print.

Silver, Kenneth. "Sarah Bernhardt and the Theatrics of French Nationalism: From Roland's Daughter to Napoleon's Son." Ockman and Silver 75-98.

Simon, Jessica. "Conjuring the Dancer and the Dance: Salomé and the Dynamics of the Ekphrastic Encounter." MA thesis. Columbia U, 2010. Print.

States, Bert O. Great Reckonings in Little Rooms: On the Phenomenology of Theater. Berkeley: U of California $P, 1985$. Print.

Stokes, John. Section on Sarah Bernhardt. Bernhardt, Terry, Duse: The Actress in Her Time. By Stokes, Michael R. Booth, and Susan Bassnett. Cambridge: Cambridge UP, 1988. Print.

Tocqueville, Alexis de. Democracy in America. Trans. Gerald B. Evan. London: Penguin, 2003. Print.
Truth 19 July 1883: n.p. CL 10.16 .

Vassault, Lawrence S. "Sarah Bernhardt." Cosmopolitan Apr. 1901: 567-78. Print.

Walkowitz, Judith. "The 'Vision of Salome': Cosmopolitanism and Erotic Dancing in Central London, 1908-1918." American Historical Review 108.2 (2003): 337-76. Print.

Wilde, Oscar. "The Censure and Salomé: An Interview with Mr. Oscar Wilde.” Pall Mall Gazette 29 June 1892. Nineteenth Century British Library Newspapers. Web. 13 July 2011.

. "Literary and Other Notes III." Selected Journalism. Ed. Anya Clagworth. Oxford: Oxford World's Classics, 2004. 107-20. Print.

Salomé. Paris: PUF, 2008. Print. 